\title{
Radioimmunoassay of Oxidized Calmodulin in Chloramine-T Treated Tissue Samples
}

\author{
By $A$. Biber and K. Hempel \\ Institut für Med. Strahlenkunde der Universität Würzburg
}

(Received July $15 /$ November 18,1983 )

Summary: We found that a short incubation of calmodulin with chloramine- $\mathrm{T}$ alters its antigenic structure. Antisera elicited by performic acid oxidized calmodulin only bind with chloramine-T treated calmodulin.

Based on this finding we have developed an assay for the determination of calmodulin in small tissue samples. Tissue homogenates are incubated with $10 \mathrm{mmol} / \mathrm{l}$ chloramine-T before calmodulin quantification. Immune complexes are isolated by sodium sulphate precipitation. $\left[{ }^{125} \mathrm{I}\right]$ calmodulin is used as tracer.

\section{Radioimmunologische Bestimmung von oxidiertem Calmodulin in Chloramin- $T$ behandelten Proben}

Zusammenfassung: Wir fanden, daß eine kurze Inkubation von Calmodulin mit Chloramin- $T$ seine antigene Struktur ändert. Antisera, die gegen Perameisensäure-oxidiertes Calmodulin gerichtet sind, reagierten nur mit Chloramin-T behandeltem Calmodulin.

Auf dieser Beobachtung aufbauend, entwickelten wir ein Verfahren für die Bestimmung von Calmodulin in Gewebeproben. Das Gewebshomogenat wird vor der Calmodulin-Bestimmung mit $10 \mathrm{mmol} / \mathrm{l}$ Chloramin-T inkubiert. Immunkomplexe wurden nach Ausfällen mit Natriumsulfat isoliert. [ ${ }^{125} \mathrm{I}$ ]Calmodulin diente als Tracer.

\section{Introduction}

Calmodulin is a widely distributed calcium binding protein, which regulates the activity of many enzymes such as phosphodiesterase and adenylate cyclase in a calcium dependent manner. Drugs such as phenothiazine antipsychotics and several structurally related compounds have been shown to inhibit the action of calmodulin by binding directly to it (1), whereas chronic haloperidol treatment increases the calmodulin content in striatal membranes and produces supersensitivity of striatal dopamine receptors (2). Therefore the knowledge of the calmodulin content of tissue might be in many cases a prerequisite for the better understanding of drug effects.

Several radioimmunoassays have been developed for the quantification of calmodulin $(3,4,5)$. The main problem is to elicit antibodies since calmodulin has an ubiquitous distribution and a highly conserved structure. Antisera were in general prepared by the injection of modified calmodulin. Normally these antisera had a much higher affinity to the corresponding modified calmodulin than to its native form. Therefore it was of great interest when Van Eldik \& Watterson (5) found that antisera induced by the injection of oxidized calmodulin react with oxidized as well as with unoxidized calmodulin. Unfortunately we could not confirm their results. Our calmodulin antibodies produced against oxidized calmodulin only detect the oxidized form.

The present contribution describes a rapid and reliable radioimmunoassay for the measurement of calmodulin in small tissue samples. In contrast to the radioimmunoassay for calmodulin of Van Eldik \& Watterson (5), we treat calmodulin before the determination with chloramine-T. Sodium sulphate is used to precipitate the antigen-antibody complex. 


\section{Materials and Methods}

\section{Isolation and modification of calmodulin}

Calmodulin was isolated from pig brain (6). Because it is known that calmodulin is a poor antigen we modified the protein in order to increase immunogenity as described with performic acid (5) and 1-fluoro-2,4-dinitrobenzene (3). The purity of calmodulin used for these experiments was checked by SDS-polyacrylamide gel electrophoresis (7) and isoelectric focusing (8) and found to be better than $94 \%$.

\section{Antibody production}

Heat denatured, performic acid oxidized or dinitrophenylated calmodulin was used as immunogen. Oxidized calmodulin was dissolved in $200 \mu \mathrm{l}$ saline and emulsified in a mixture of $200 \mu \mathrm{l}$ aluminium hydroxide gel (Superfos Comp., Denmark) and $400 \mu \mathrm{l} \mathrm{com-}$ plete Freund's adjuvant (Behringwerke, Marburg, FRG). The complete Freund's adjuvant used contained $1 \mathrm{~g} / \mathrm{l}$ heat-killed $m y$ cobacterium tuberculosis. Eight rabbits of either sex received $1 \mathrm{mg}$ of the antigen by intracutaneous injection in 4 to 5 sites on the back. Animals were boosted with the identical antigen $(0.5 \mathrm{mg}$ per animal) 7,14 and 28 days later. Immunization against heat denatured or dinitrophenylated calmodulin was performed as described above for oxidized calmodulin, except that boosts were given monthly for half a year. No clinical abnormalities appeared in the animals during the course of immunization. Serum obtained from the blood of the ear vein was stored at $-30^{\circ} \mathrm{C}$.

\section{Radioiodination of calmodulin}

\section{Method A}

Normally the chloramine-T method was used (9). Briefly, $10 \mu \mathrm{g}$ calmodulin in $20 \mu \mathrm{l} 0.1 \mathrm{~mol} / \mathrm{l}$ sodium phosphate buffer $\mathrm{pH} 7.0$ was incubated at room temperature for $30 \mathrm{~s}$ with $10 \mu \mathrm{l} 4 \mathrm{mmol} / \mathrm{l} \mathrm{chlo-}$ ramine-T and $10 \mu \mathrm{l}{ }^{125} \mathrm{I}(\mathrm{NaI}, 37 \mathrm{MBq})(\mathrm{NEN}$, Dreieich, FRG), spec act. $63 \mathrm{MBq} / \mu \mathrm{g}=17 \mathrm{mCi} / \mu \mathrm{g}$. The reaction was stopped by $20 \mu \mathrm{l} 8 \mathrm{mmol} / \mathrm{l}$ sodium metabisulfite and the mixture was transferred to an Ultrogel AcA 54 (LKB, Sweden) column $(1.5 \times 40$ $\mathrm{cm}$ ) and labelled calmodulin was eluted at $4{ }^{\circ} \mathrm{C}$ with $1 \mathrm{~mol} / \mathrm{l}$ sodium acetate $\mathrm{pH} 7.0$ supplemented with $1 \mathrm{~g} / \mathrm{l}$ bovine serum albumin (Sigma Comp., USA; crystallized and lyophilized albumin, essentially globulin-free) and $1 \mathrm{~g} / \mathrm{KI}$. The specific activity was about $18 \mathrm{TBq} / \mathrm{mmol}(500 \mathrm{Ci} / \mathrm{mmol})$. More than $90 \%$ of the radioactivity co-migrated with cold calmodulin in SDS-polyacrylamide gel electrophoresis or in isoelectric focusing.

\section{Method B}

In some experiments 1,3,4,6-tetrachloro-3 $\alpha, 6 \alpha$-diphenyl-glycoluril (Iodogen, Pierce Eurochemie BV, Rotterdam, NL) was used as follows (10): To $20 \mu \mathrm{g}$ Iodogen ("plated" in a micro glass vial from chloroform solution) was added $100 \mu \mathrm{l} 0.1 \mathrm{~mol} / \mathrm{l}$ phosphate buffer $\mathrm{pH} 7.0,10 \mu \mathrm{l}$ protein solution $(10 \mu \mathrm{g})$ and $10 \mu \mathrm{l}^{125} \mathrm{I}(37$ $\mathrm{MBq}$ ). After reaction for $5 \mathrm{~min}$ at room temperature, the contents were transferred to an Ultrogel column as described in Method A.

\section{Method C}

Calmodulin was also conjugated to Bolton-Hunter reagent $\left({ }^{125} \mathrm{I}-\right.$ iodinated 3-(4-hydroxy-phenyl)propionic acid N-hydroxy-succinimide ester, spec. activity $74 \mathrm{TBq} / \mathrm{mmol}$, Amersham Buchler, Braunschweig) (11). Prior to use for iodination, the solvent was removed from the reagent by evaporation. Then $20 \mu \mathrm{l}$ protein $(10$ $\mu \mathrm{g}$ ) and $20 \mu \mathrm{l} 0.1 \mathrm{~mol} / \mathrm{l}$ phosphate buffer $\mathrm{pH} 8.0$ were added to the reagent (activity $37 \mathrm{MBq}$ ) and allowed to react for $1 \mathrm{~h}$ at $4^{\circ} \mathrm{C}$. Unchanged ester was reacted with $400 \mu \mathrm{l}$ of $0.2 \mathrm{~mol} / \mathrm{l}$ glycine in $0.1 \mathrm{~mol} / 1$ phosphate buffer $\mathrm{pH} 8.0$ for $1 \mathrm{~h}$ at room temperature.

\section{Sample preparation}

Tissue samples were prepared from brain and liver of Wistar-Kyoto rats. Brains were removed within 2 min after decapitation, frozen on dry-ice and cut into $300 \mu \mathrm{m}$ thick sections in a cryostat at $-10^{\circ} \mathrm{C}$. The different brain areas were removed by micro punch technique (12). Samples equal to $2-3 \mathrm{mg}$ wet weight were homogenized in an all glass Potter-Elvehjem micro tissue grinder with $100 \mu \mathrm{l} 0.2 \mathrm{~mol} / \mathrm{l}$ tris-acetate buffer $\mathrm{pH} 7.0$ (buffer A) containing $1 \mathrm{mmol} / 1$ EDTA, heated in a boiling water bath for $4 \mathrm{~min}$ to destroy endogenous proteolytic enzymes and diluted with trisacetate buffer to a final protein concentration of about $100 \mathrm{mg} / \mathrm{l}$. A part of this solution $(100 \mu \mathrm{l})$ as well as calmodulin standard were oxidized at room temperature by the addition of $100 \mu \mathrm{l} 20$ $\mathrm{mmol} / \mathrm{l}$ chloramine- $\mathrm{T}$ solution. The reaction was stopped after $2 \mathrm{~min}$ by addition of $200 \mu \mathrm{l} 40 \mathrm{mmol} / \mathrm{l}$ sodium metabisulfite.

Liver tissue was homogenized in buffer $A(1: 6 \mathrm{w} / \mathrm{v})$ heated as described above and centrifuged at $1000 \mathrm{~g}$ for $20 \mathrm{~min}$. An aliquot of the supernatant was diluted and oxidized by chloramine-T as described above.

\section{Radioimmunoassay}

The sodium sulphate method was used for separating antigen-antibody-complex from free antigen (13). The assay mixture consisted of $200 \mu$ l chloramine-T treated sample or chloramine-T treated calmodulin standard dissolved in $0.1 \mathrm{~mol} / \mathrm{l}$ tris-acetate buffer $\mathrm{pH}$ 7.0, $0.07 \mathrm{~mol} / 1 \mathrm{NaCl}, 1 \mathrm{mmol} / \mathrm{l}$ EDTA, $1 \mathrm{~g} / \mathrm{l}$ bovine serum albumin, $200 \mu \mathrm{l}$ antisera diluted $1: 30$ with bovine serum and $\left[{ }^{125} \mathrm{I}\right] \mathrm{cal}-$ modulin dissolved in $100 \mu \mathrm{l}$ bovine serum. The addition of bovine serum is necessary to obtain a bulky precipitation. After an incubation period of $3 \mathrm{~h}$ at room temperature antibody bound antigens were precipitated together with globulins by the addition of $800 \mu \mathrm{l} 1.9 \mathrm{~mol} / \mathrm{l}$ sodium sulphate. The supernatant was aspirated after centrifugation $\left(20 \mathrm{~min}, 1000 \mathrm{~g}, 20^{\circ} \mathrm{C}\right)$ and the pellet containing the antibody-bound calmodulin was washed three times with $1 \mathrm{ml} 1.27 \mathrm{~mol} / \mathrm{l}$ sodium sulphate and then counted for ${ }^{125} \mathrm{I}$ radioactivity.

\section{Phosphodiesterase assay}

Calmodulin was also measured by the stimulation of cAMP-phosphodiesterase according to Murray \& Rogers (14). The reaction mixture $(1 \mathrm{ml})$ contained $90 \mathrm{mmol} / \mathrm{l}$ glycylglycine $\mathrm{pH} 7.5,3.87$ $\mathrm{mmol} / \mathrm{l} \mathrm{CaCl}, 1.2 \mathrm{mmol} / \mathrm{l} \mathrm{MgSO}{ }_{4}, 10 \mu \mathrm{g}$ adenosine deaminase, $20 \mu \mathrm{g}$ alkaline phosphatase (from calf intestine), $3 \mathrm{mU}$ phosphodiesterase (all enzymes were from Boehringer Mannheim, FRG), $90 \mu \mathrm{mol} / \mathrm{l}$ cAMP and an appropriate amount of calmodulin $(10-200 \mathrm{ng})$. The conversion of cAMP into inosine was measured at $265 \mathrm{~nm}$.

\section{Protein determination}

An aliquot $(100 \mu \mathrm{l})$ of the tissue homogenate was treated with $100 \mathrm{~g} / \mathrm{l}$ trichloroacetic acid. After centrifugation $(10 \mathrm{~min}, 1000 \mathrm{~g}$, $4^{\circ} \mathrm{C}$ ) the precipitate was redissolved in $200 \mu \mathrm{l} 30 \mathrm{~g} / 1 \mathrm{NaOH}$ containing $10 \mathrm{~g} / \mathrm{l} \mathrm{SDS}$ and the protein was determined by the biuret method.

\section{Materials}

Troponin and parvalbumin were from Sigmạ, USA. 


\section{Results and Discussion}

Seven out of eight rabbits immunized against performic acid oxidized calmodulin developed antibodies. Figure 1 shows the specificity of the antisera. [125I]Calmodulin was bound by the antibody but only oxidized calmodulin competes with radioiodinated calmodulin for the binding sites. Calmodulin was oxidized by performic acid or chloramine- $T$ as described in Methods. Structurally and functionally related proteins such as parvalbumin and troponin did not cross-react even after prior oxidation.

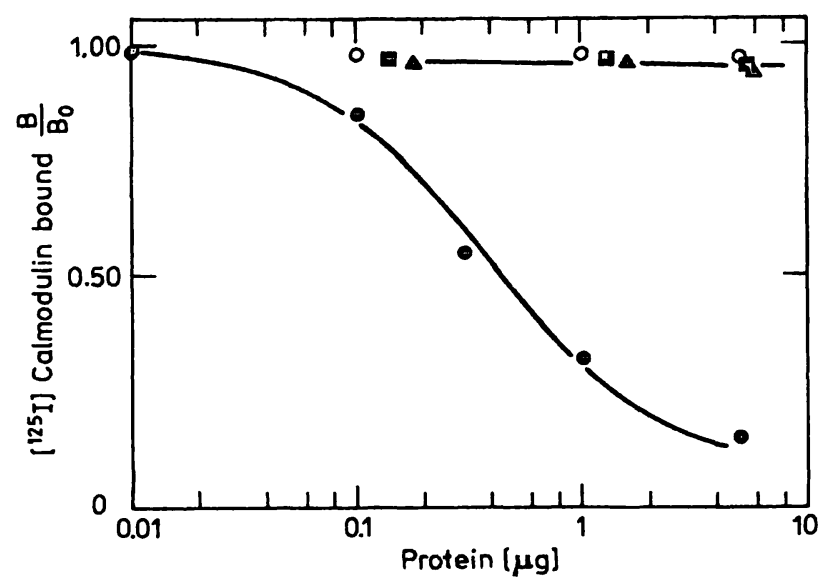

Fig. 1. Immunoreactivity of calmodulin and related proteins in competition radioimmunoassay.

Various amounts of competing proteins were mixed with antiserum and incubated with $\left[{ }^{125} I\right]$ calmodulin as described in Methods. The antiserum was induced in rabbit by performic acid oxidized calmodulin. Maximal binding $0.2\left(=\mathrm{B}_{0}\right)$, unspecific 0.02 . Competing proteins: $O$ native calmodulin

o chloramine- $T$ treated calmodulin

$\Delta$ chloramine-T treated parvalbumin

D chloramine-T treated troponin.

The affinity of $\left.{ }^{125} \mathrm{I}\right] \mathrm{calmodulin}$ to the antisera depended on the method of radioiodination. If chloramine-T (method A) or Iodogen (method B) were used, the affinity of iodinated calmodulin to the antibody was high, whereas calmodulin labelled with Bolton-Hunter reagent (method C) did not bind at all. Chloramine $-\bar{T}$ and lodogen are oxidizing reagents, which oxidize not only iodide but also the methionine residues (15) and induce structural changes of calmodulin (16). Bolton-Hunter labelled calmodulin did not react with the antisera most probably because this is a non-oxidizing iodination.

The present study contradicts the results of $\mathrm{Van} \mathrm{El-}$ dik \& Watterson (5) with respect to the immunospecificity of antisera induced by oxidized calmodulin. They stressed that the reactivities of oxidized and unoxidized calmodulin were indistinguishable with these antisera. Methodical differences might be the reason for this discrepancy. Therefore, we performed some preliminary experiments with their antisera and precipitated the antigen-antibody complex with $\mathrm{Na}_{2} \mathrm{SO}_{4}$ as described in Methods. We found that under these conditions also, their antibody only reacts with oxidized calmodulin. These experiments were performed with $\left[{ }^{125} \mathrm{I}\right]$ calmodulin iodinated by the chloramine-T method. Differences in calmodulin oxidation during the radioiodination could explain this discrepancy.

In addition we tried to induce anti-calmodulin antibodies by methods described by other investigators. In these experiments heat denatured calmodulin (4) and dinitro-phenylated calmodulin (3) were used as immunogens. The first antigen did not elicit any anticalmodulin reactivity. The second one induced in all five animals only antibodies against the dinitrophenylated protein, whereas Wallace \& Cheung reported reactivity of these antibodies with calmodulin (3).

From the results given in figure 1 it is evident that antisera induced by oxidized calmodulin only detect the oxidized protein. Thus these sera are unsuitable for the determination of calmodulin in tissue unless calmodulin is oxidized prior to its quantification. A 2 min treatment with $10 \mathrm{mmol} / \mathrm{l}$ chloramine- $\mathrm{T}$ is sufficient to give full immunochemical reactivity (fig. 2). The same result was found when calmodulin was oxidized in the presence of tissue homogenates. Amino acid analyses of chloramine- $T$ treated calmodulin showed a decrease in methionine as described (15).

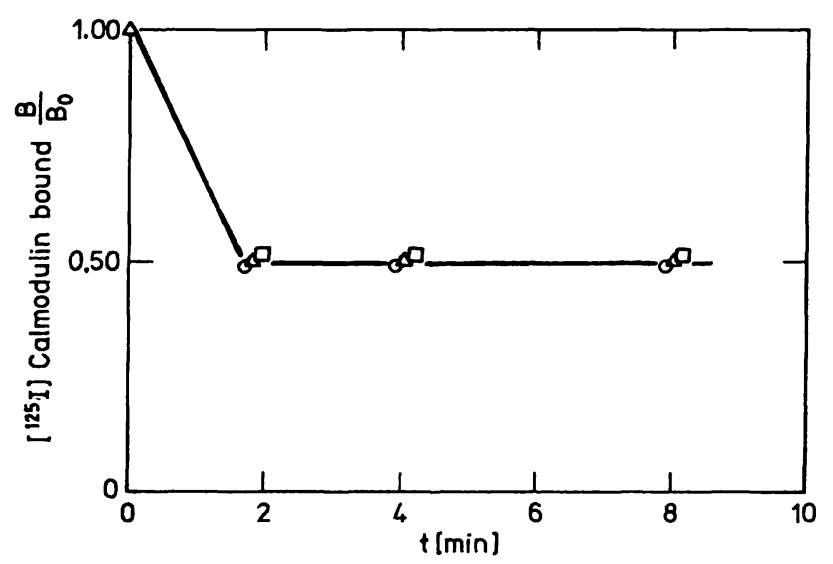

Fig. 2. Alteration of the immunoreactivity of calmodulin by pretreatment with chloramine- $T$.

Calmodulin (500 ng) dissolved in $100 \mu \mathrm{l} 0.1 \mathrm{~mol} / \mathrm{l}$ Tris acetate buffer $\mathrm{pH} 7.0,0.07 \mathrm{~mol} / 1 \mathrm{NaCl}, 1 \mathrm{mmol} / \mathrm{I} \mathrm{EDTA}$, $1 \mathrm{~g} / \mathrm{l}$ bovine serum albumin was treated with $100 \mu \mathrm{l}$ chloramine- $T$ solution $(O 1 \mathrm{mmol} / \mathrm{l}, \Delta 10 \mathrm{mmol} / \mathrm{l}, \square 50$ $\mathrm{mmol} / \mathrm{l}$ ). The reaction was stopped 2 to $10 \mathrm{~min}$ later by the addition of $100 \mu \mathrm{l}$ metabisulfite solution. Then $\left[{ }^{125} \mathrm{I}\right]$ calmodulin and antiserum were added and the amount of antibody bound label was determined. 
The calmodulin content of some brain areas was measured by radioimmunoassay and the values are compared with those obtained by an enzyme method (tab. 1). The enzyme assay confirmed the results obtained by the radioimmunoassay, although the amounts were lower. This underestimate by the enzyme-assay has been observed by others $(4,17)$ and may be due to calmodulin-binding proteins (3).

Tab. 1. Calmodulin content in specific brain areas from the rat. Areas were removed by the punch technique (12).

\begin{tabular}{lcc}
\hline Brain Area & \multicolumn{2}{c}{ Calmodulin $(\mu \mathrm{g} / \mathrm{mg}$ protein)* } \\
& Immunoassay & Enzyme assay \\
\hline Cortex cinguli & $14 \pm 3(9)$ & 9 \\
Cortex frontalis & $16 \pm 3(7)$ & 12 \\
Hippocampus & $12 \pm 3(7)$ & 9 \\
Striatum & $15 \pm 5(5)$ & 12 \\
Locus coeruleus & $7 \pm 1(4)$ & 3 \\
\hline
\end{tabular}

* mean values $\pm \mathrm{SD}$, number of determinations in brackets

For testing reproducibility of the radioimmunoassay two persons independently measured thirty times the calmodulin content of the same rat liver (tab. 2). The mean values of the two estimation series are in good agreement. In each case the coefficient of variation was less than 0.10 .

\section{References}

1. Levin, R. M. \& Weiss, B. (1976) Molec. Pharmacol. 12, 581-589.

2. Gnegy, M. E. (1982) Federation Proc. 41, 2273-2277.

3. Wallace, R. W. \& Cheung, W. Y. (1979) J. Biol. Chem. 254, 6564-6571.

4. Chafouleas, J. M., Dedman, J. R., Munjaal, R. P. \& Means, A. R. (1979) J. Biol. Chem. 254, 10262-10267.

5. Van Eldik, L. J. \& Watterson, D. M. (1981) J. Biol. Chem. 256, 4205-4210.

6. Gopalakrishna, R. \& Anderson, W. B. (1982) Biochem. Biophys. Res. Commun. 104, 830-836.

7. Esposito, J. \& Obijeski, J. F. (1976) Prep. Biochem. 6, 431-434.

8. Delmotte, P. (1971) J. Clin. Chem. Clin. Biochem. 9, 334-336.

9. Hunter, W. M. \& Greenwood, F. C. (1962) Nature 194, 495-496.
Tab. 2. Reproducibility of the calmodulin RIA. Repeated calmodulin determination in the same rat liver.

\begin{tabular}{ll}
\hline Performal by & Calmodulin (ng/mg protein)* \\
\hline Person A & $1051 \pm 89(18)$ \\
Person B & $1075 \pm 91(12)$ \\
\hline
\end{tabular}

* Mean values $\pm \mathrm{SD}$, number of determinations in brackets

Besides the induction of antibodies, changes in calmodulin conformation are the major problem in the radioimmunological determination of this protein. The conformation can easily be changed by heat or oxidation. Heat pretreatment increases the immunoreactivity of calmodulin considerably. Therefore the calmodulin content found depends on sample preparation. We have found that the combination of heat pretreatment and chloramine- $T$ oxidation permits the quick and reproducible radioimmunological determination of calmodulin in tissue using antisera against performic acid oxidized calmodulin.

\section{Acknowledgements}

We thank Dr. Linda Van Eldik and Dr. Watterson for a gift of their anti-calmodulin sera and Dr. G. Schmid for providing brain tissue samples. The skilfull technical assistance of Gertrud Kuhnhäuser is gratefully acknowledged.

10. Fraker, P. J. \& Speck, J. C. (1978) Biochem. Biophys. Res. Commun. 80, 849-857.

11. Bolton, A. E. \& Hunter, W. M. (1973) Biochem. J. 133, 529-539.

12. Palkovits, M. (1973) Brain Res. 59, 449-450.

13. Day, E. D. \& Pitts, O. M. (1974) Immunochemistry 11, $651=659$.

14. Murray, A. W. \& Rogers, A. (1978) Biochem. J. 176, 727-732.

15. Wood, W. G., Wachter, C. \& Scriba, P. C. (1981) J. Clin. Chem. Clin. Biochem. 19, 1051-1056.

16. Walsh, M. \& Stevens, F. C. (1978) Biochemistry 17, 3924-3930.

17. MacManus, J. P., Braceland, B. M., Rixon, R. H., Whitfield, J. F. \& Morris, H. P. (1981) FEBS Lett. 133, 99-102.

Prof. Dr. Dr. K. Hempel

Institut für Med. Strahlenkunde

der Universität

Versbacher Str. 5

D-8700 Würzburg 